\title{
Improving Students' Speaking Skill Through Drama at the Eighth Grade of SMPN 9 Palopo
}

\author{
Marwati \\ State Islamic Institute of Palopo (IAIN Palopo), Indonesia \\ marwati@iainpalopo.ac.id
}

\begin{abstract}
This paper dealt with the effectiveness of drama techniques in enhancing student speech at SMPN 9 Palopo in 8th grade. The research was mainly sample. This investigation was carried out in two classes: experimental and control classes. Sixty students from VIII SMPN 9 Palopo graduates attended this research. The sample of research for the level of VIII 6 was 30 students as experimental classes, and the class of 8 / 1 was composed of 30 students. The method is voice check-in research. The students will be evaluated and assessed by this study. SPSS, 20 , analyzed the data. Data were analyzed. The study results show that the use of dramatic materials can improve the skills of speakers. The calculation results show that the scores of students in the experimental class are better than the scores of students in the control class. Based on data analysis, a post-test average value of $10,5300>7,5700$ is higher than the pre-test average. The average value in the control class is also more significant than the average preliminary value. Based on the analysis of the data, the lesson of speech using effective dramatic techniques at 9 Palopo can be concluded. It can be concluded. The results of the experimental classes can be shown that they are higher than the control class.
\end{abstract}

Keywords: Drama Technique, English Language Teaching, Speaking Skills.

\section{INTRODUCTION}

Speaking skills are language skills developed in a child's life that come from listening to skills are learned. Speaking is one way to communicate and communicate ideas orally. That is why speaking was very important. The learner of a language should have good skills in the language (Iksan \& Palangngan, 2018). Especially, to avoid a possible misunderstanding in communication. In learning language, the learner of the language may use different ways to develop their speaking ability, for example, debate, speech, and discussion. English teachers should be able to fulfil the role of a professional teacher. A teacher should participate in the teaching-learning process. Other ways are having group discussions doing role-play, dramatic techniques, and these games can reduce the' well-being of the student and enable the students to socialize with others certainly and can cause nice competition between them. English teacher SMPN 9 Palopo should implement appropriate teaching methods and techniques. So to succeed this method teachers need technique and one of them is using drama techniques. Why use drama? Because they combine verbal and non-verbal elements, so they unite the mind and body and restore the balance between the physical and the intellectual aspects of studying Drama. Why drama is important because in studying drama students are able to be confident in doing everything. For example, speaking in public. The benefit of learning 
drama for students is to improve memory for students, help students with language skill and confidence, support character to give birth to their respective creative powers and eliminate shyness, nervousness, tension and fear. Based on the surface survey wants to identify for the problem, is the using for Drama is potent in repairing students' speaking skills in SMPN 9 Palopo? Purpose of the survey is to improve college speaking skill to take drama technique at eighth class SMP of 9 Palopo.

\section{METHODS}

\section{Research Design}

This research applied quasi-experimental research design. Quasi-experimental was involved in two groups for college with pre-test and post-test pattern. According to Ary et al, quasi-experimental is an experimental research design that has lacks the randomization of the group. Quasi-experimental needed two similar groups as the sample of the research. Latief states that quasi-experimental research is the research which takes the sample from two different classes in the same grades which has similarity. The classes are an experimental group and a control group. The experimental group was the group who teaches improving speaking skills students through drama. The other hand, the control group was the group who does not teach improving speaking skill students through drama. The researcher was used pre-test and post-test in both experimental and control classes. The aim to find out the using of improving speaking skills students through drama and to get the effectiveness significant by comparing the pre-test and post-test both of the experimental class and control class. The research design in this research could be seen as follows:

\begin{tabular}{lcccc}
\hline Group & \multicolumn{1}{c}{ Pre-test } & Treatment & Post-test \\
\hline $\mathrm{E}$ & $\mathrm{O}_{1}$ & & $\mathrm{X}$ & $\mathrm{O}_{2}$ \\
$\mathrm{C}$ & & $\mathrm{O}_{3}$ & & $\mathrm{O}_{4}$
\end{tabular}

Where:
E : Experimental Class
C : Controlled Class
01 : Result of Pre-test (in experimental class)
03 : Result of Pre-test (in controlled class)
$\mathrm{X}$ : Treatment that will be given for experimental class
02 : Result of Post-test (in experimental class)
04 : Result of Post-test (in controlled class).

(Sugiyono, 2014)

\section{Location and Time of Research}

The researcher decided to research in SMPN 9 Palopo, at eighth grade Class 1 as control class and eighth grade 6 as an experimental class. The researcher decided to research starting from October $21^{\text {st }}$ to November $7^{\text {th }}, 2019$.

\section{Variables}


In this research, these are two categories of variables, namely the Dependent variable is to improve students' speaking skill. The independent variable is Drama.

\section{Population and Samples}

The population of this research was the eighth-grade student's of SMPN 9 Palopo in the $2019 / 2020$ academic year. The total population of 60 students from 2 classes, there are class VIII 1 and VIII 6 . The samples of the research were chosen purposively. It consisted of 30 students for each class. There are 22 boys and 38 girls. They have the same proficiency level they still have low achievement in speaking.

\section{Etiquette for trove Data Pre-test}

The first thing to do is the researcher applied a pre-test. Students in the class join the test. The researcher had given a question to oral questions students about themselves, experiences and desire to be achieved. The researcher had given an example of an unforgettable experience.

\section{Experimental and Control Class}

The English teaching of Speaking skills at both classes was conducted for four meetings for each. The teaching in Experimental classes was conducted following the procedure of The Drama Technique, while in control class, the teaching process was following the conventional method.

\section{Post-Test}

The post-test was conducted to find out the students' achievement and their progress after giving the treatment about improving speaking skills through Drama. The researcher gave a Drama entitled about asking suggestion and giving suggestion.

\section{Research of the Instrument}

The instrument of this research was speaking skill through drama at SMPN 9 Palopo in class VIII 1 and VIII 6, from that the test the researcher scored the students' Accuracy, fluency, and comprehensibility. The researcher was a useful test to measure the students' ability to understand the speaking skill before and after giving treatments. In this case, speaking skill is an objective test.

\section{The technique of Data Analysis}

The researcher used quantitative analysis to find the default value and deviation of the data and t-test paired sample by used SPSS 20.0.

\section{RESULTS}

\section{Students Score of Experimental Class Students' Pre-test Result}

Table 4.1 The Score of college Pre-test Result in Experimental Class 


\begin{tabular}{|c|c|c|c|c|}
\hline Respondents & exactness & Smoothness & Comprehensibility & Students score \\
\hline R1 & 4 & 4 & 4 & 12 \\
\hline $\mathrm{R} 2$ & 4 & 3 & 4 & 11 \\
\hline R3 & 3 & 2 & 2 & 7 \\
\hline R4 & 3 & 2 & 2 & 7 \\
\hline R5 & 3 & 3 & 2 & 8 \\
\hline R6 & 2 & 2 & 2 & 6 \\
\hline R7 & 3 & 3 & 3 & 9 \\
\hline R8 & 2 & 2 & 2 & 6 \\
\hline R9 & 2 & 2 & 2 & 6 \\
\hline R10 & 3 & 3 & 2 & 9 \\
\hline R11 & 3 & 3 & 2 & 8 \\
\hline R12 & 3 & 3 & 2 & 8 \\
\hline R13 & 3 & 3 & 2 & 8 \\
\hline R14 & 3 & 3 & 3 & 9 \\
\hline R15 & 2 & 3 & 3 & 8 \\
\hline R16 & 2 & 3 & 3 & 8 \\
\hline R17 & 2 & 2 & 3 & 7 \\
\hline R18 & 2 & 2 & 2 & 6 \\
\hline R19 & 2 & 2 & 1 & 5 \\
\hline R20 & 2 & 2 & 2 & 6 \\
\hline R21 & 2 & 1 & 1 & 4 \\
\hline R22 & 2 & 3 & 2 & 6 \\
\hline R23 & 3 & 2 & 3 & 8 \\
\hline R24 & 2 & 2 & 3 & 7 \\
\hline R25 & 2 & 3 & 2 & 7 \\
\hline R26 & 3 & 3 & 2 & 8 \\
\hline R27 & 3 & 3 & 3 & 9 \\
\hline R28 & 3 & 2 & 3 & 8 \\
\hline R29 & 3 & 3 & 3 & 8 \\
\hline R30 & 3 & 3 & 2 & 8 \\
\hline
\end{tabular}

Table 4.3 The of students' score Rate Percentage Accuracy in Pretest Result in Class Experimental

\begin{tabular}{|c|c|c|c|}
\hline Method & Rating & Frequency & Percentage \\
\hline Excellent & 6 & - & $0 \%$ \\
\hline Very good & 5 & - & $0 \%$ \\
\hline Good & 4 & 2 & $7 \%$ \\
\hline Average & 3 & 15 & $50 \%$ \\
\hline Poor & 2 & 13 & $43 \%$ \\
\hline Very poor & 1 & - & $0 \%$ \\
\hline \multicolumn{2}{|c|}{ Total } & 30 & $100 \%$ \\
\hline
\end{tabular}

Table 4.5 The Rate Percentage of Students' Score of Fluency in Pretest Result in Experimental Class 


\begin{tabular}{|c|c|c|c|}
\hline Classification & Rating & Frequency & Percentage \\
\hline Excellent & 6 & - & $0 \%$ \\
\hline Very good & 5 & - & $0 \%$ \\
\hline Good & 4 & 1 & $3 \%$ \\
\hline Average & 3 & 16 & $54 \%$ \\
\hline Poor & 2 & 12 & $40 \%$ \\
\hline Very poor & 1 & 1 & $3 \%$ \\
\hline \multicolumn{2}{|c|}{ Total } & 30 & $100 \%$ \\
\hline
\end{tabular}

Table 4.7 The Rate Percentage Score of comprehensibility in Pretest Result in Experimental Class

\begin{tabular}{|c|c|c|c|}
\hline Classification & Rating & Frequency & Percentage \\
\hline Excellent & 6 & - & $0 \%$ \\
\hline Very good & 5 & - & $0 \%$ \\
\hline Good & 4 & 2 & $7 \%$ \\
\hline Average & 3 & 10 & $33 \%$ \\
\hline Poor & 2 & 16 & $53 \%$ \\
\hline Very poor & 1 & 2 & $7 \%$ \\
\hline \multicolumn{2}{|c|}{ Total } & 30 & $100 \%$ \\
\hline
\end{tabular}

\section{Students' Posttest Result}

Table 4.8 The Students' Score Posttest Result in Experimental Class

\begin{tabular}{ccccc}
\hline & \multicolumn{3}{c}{ The speaking Aspects of Skill } & \\
\cline { 2 - 4 } Respondents & \multicolumn{2}{c}{ Students } \\
& Exactness & Smoothes & Comprehensibility & \\
score \\
R1 & 5 & 4 & 6 & 15 \\
R2 & 4 & 4 & 4 & 12 \\
R3 & 4 & 3 & 3 & 10 \\
R4 & 4 & 3 & 3 & 10 \\
R5 & 4 & 4 & 3 & 11 \\
R6 & 3 & 3 & 3 & 9 \\
R7 & 4 & 4 & 4 & 12 \\
R8 & 3 & 3 & 3 & 9 \\
R9 & 4 & 4 & 3 & 11 \\
R10 & 4 & 4 & 3 & 11 \\
R11 & 4 & 4 & 3 & 11 \\
R12 & 4 & 4 & 4 & 12 \\
R13 & 4 & 4 & 2 & 9 \\
R14 & 3 & 4 & 2 & 10 \\
R15 & 4 & 3 & 4 & 12 \\
R16 & 3 & 3 & 4 & 9 \\
R17 & 4 & 4 & & \\
\hline
\end{tabular}




\begin{tabular}{ccccc}
\hline R18 & 3 & 3 & 2 & 8 \\
R19 & 3 & 3 & 3 & 9 \\
R20 & 3 & 3 & 3 & 9 \\
R21 & 3 & 4 & 3 & 10 \\
R22 & 3 & 3 & 3 & 9 \\
R23 & 3 & 4 & 3 & 10 \\
R24 & 4 & 4 & 3 & 11 \\
R25 & 4 & 4 & 4 & 12 \\
R26 & 4 & 3 & 4 & 11 \\
R27 & 4 & 4 & 3 & 12 \\
R28 & 4 & 4 & 4 & 11 \\
R29 & 3 & 3 & 2 & 10 \\
R30 & 4 & 3 & & 10 \\
\hline
\end{tabular}

Table 4.10 The Percentage Rate Score students of Accuracy in Posttest Result in Class Experimental

\begin{tabular}{cccc}
\hline Classification & Rating & Frequency & Percentage \\
\hline Excellent & 6 & - & $0 \%$ \\
Very good & 5 & 1 & $3 \%$ \\
Good & 4 & 18 & $60 \%$ \\
Average & 3 & 11 & $37 \%$ \\
Poor & 2 & - & $0 \%$ \\
Very poor & 1 & - & $0 \%$ \\
\hline & Total & 30 & $100 \%$ \\
\hline
\end{tabular}

Table 4.12 The percentage Rate value of Students' smoothes in Posttest Result in Experimental Class

\begin{tabular}{|c|c|c|c|}
\hline Classification & Rating & Frequency & Percentage \\
\hline Excellent & 6 & - & $0 \%$ \\
\hline Very good & 5 & - & $5 \%$ \\
\hline Good & 4 & 17 & $57 \%$ \\
\hline Average & 3 & 13 & $43 \%$ \\
\hline Poor & 2 & - & $0 \%$ \\
\hline Very poor & 1 & - & $0 \%$ \\
\hline \multicolumn{2}{|c|}{ Total } & 30 & $100 \%$ \\
\hline
\end{tabular}

Table 4.14 The Rate Percentage Score of Students' Comprehensibility in Posttest Result in Experimental Class

\begin{tabular}{cccc}
\hline Classification & Rating & Frequency & Percentage \\
\hline Excellent & 6 & 1 & $3 \%$ \\
Very good & 5 & - & $0 \%$ \\
Good & 4 & 9 & $30 \%$
\end{tabular}




\begin{tabular}{ccccc} 
Average & 3 & 17 & $57 \%$ \\
Poor & 2 & 3 & $10 \%$ \\
Very poor & 1 & - & $0 \%$ \\
\hline & Total & & 30 & $100 \%$ \\
\hline
\end{tabular}

Table 4.15 The Mean Score of Students' Pretest in Experimental Class Statistic Descriptive

\begin{tabular}{lcccccc}
\hline & N & Minimum & Maximum & Sum & Mean & Std. Deviation \\
\hline Pretest exp & 30 & 4 & 12 & 227 & 7.57 & 1.633 \\
Valid N (listwise) & 30 & & & & & \\
\hline
\end{tabular}

Table 4.16 The Mean Score of Students' Posttest in Class Experimental Statistic Descriptive

\begin{tabular}{lcccccc}
\hline & N & Minimum & Maximum & Sum & Mean & Std. Deviation \\
\hline Posttest exp & 30 & 8 & 15 & 316 & 10.53 & 1.432 \\
Valid N (listwise) & 30 & & & & &
\end{tabular}

\section{Students Score of Control Class}

Students' Pretest Result

Table 4.17 The Score of Students' Pretest Result in Control Class

\begin{tabular}{ccccc}
\hline & \multicolumn{3}{c}{ The speaking skills of Aspects } & \\
\cline { 2 - 4 } Respondents & & & \\
& Exactness & Smoothness & Comprehensibility & \\
\hline R1 & 2 & 3 & 3 & 5 \\
R2 & 3 & 2 & 3 & 5 \\
R3 & 3 & 4 & 3 & 8 \\
R4 & 3 & 2 & 2 & 4 \\
R5 & 3 & 3 & 2 & 5 \\
R6 & 3 & 2 & 2 & 4 \\
R7 & 3 & 3 & 2 & 5 \\
R8 & 4 & 4 & 2 & 8 \\
R9 & 3 & 4 & 4 & 8 \\
R10 & 4 & 4 & 2 & 5 \\
R11 & 2 & 3 & 2 & 5 \\
R12 & 3 & 3 & 3 & 5 \\
R13 & 2 & 3 & 3 & 6 \\
R14 & 3 & 2 & 2 & 5 \\
R15 & 3 & 3 & 3 & 6 \\
R16 & 3 & 3 & 4 & 5 \\
R17 & 3 & 3 & 3 & 8 \\
R18 & 3 & 2 & 4 & 5 \\
R19 & 3 & 4 & & \\
\hline
\end{tabular}




$\begin{array}{lllll}\mathrm{R} 20 & 2 & 3 & 2 & 4 \\ \mathrm{R} 21 & 4 & 4 & 3 & 9 \\ \mathrm{R} 22 & 3 & 3 & 3 & 6 \\ \mathrm{R} 23 & 2 & 3 & 3 & 5 \\ \mathrm{R} 24 & 3 & 4 & 2 & 8 \\ \mathrm{R} 25 & 3 & 3 & 2 & 6 \\ \mathrm{R} 26 & 3 & 2 & 2 & 4 \\ \mathrm{R} 27 & 2 & 3 & 2 & 4 \\ \mathrm{R} 28 & 3 & 3 & 3 & 5 \\ \mathrm{R} 29 & 2 & 3 & 2 & 5 \\ \mathrm{R} 30 & 2 & 3 & & 4\end{array}$

Table 4.18 The percentage Rate Score of Students' Accuracy in Pretest Result in Class Control

\begin{tabular}{|c|c|c|c|}
\hline Classification & Rating & Frequency & Percentage \\
\hline Excellent & 6 & - & $0 \%$ \\
\hline Very good & 5 & - & $0 \%$ \\
\hline Good & 4 & - & $0 \%$ \\
\hline Average & 3 & 3 & $10 \%$ \\
\hline Poor & 2 & 18 & $60 \%$ \\
\hline Very poor & 1 & 9 & $30 \%$ \\
\hline \multicolumn{2}{|c|}{ Total } & 30 & $100 \%$ \\
\hline
\end{tabular}

Table 4.19 The Rate Percentage Score of Students' Fluency in Pretest Result in Control Class

\begin{tabular}{|c|c|c|c|}
\hline Classification & Rating & Frequency & Percentage \\
\hline Excellent & 6 & - & $0 \%$ \\
\hline Very good & 5 & - & $0 \%$ \\
\hline Good & 4 & - & $0 \%$ \\
\hline Average & 3 & 7 & $23 \%$ \\
\hline Poor & 2 & 17 & $57 \%$ \\
\hline Very poor & 1 & 7 & $20 \%$ \\
\hline \multicolumn{2}{|c|}{ Total } & 30 & $100 \%$ \\
\hline
\end{tabular}

Table 4.20 The Rate Percentage Score of Students' Comprehensibility in Pretest Result in Control Class

\begin{tabular}{cccc}
\hline Classification & Rating & Frequency & Percentage \\
\hline Excellent & 6 & - & $0 \%$ \\
Very good & 5 & - & $0 \%$ \\
Good & 4 & - & $0 \%$ \\
Average & 3 & 5 & $17 \%$ \\
Poor & 2 & 15 & $50 \%$
\end{tabular}




\begin{tabular}{ccccc} 
Very poor & 1 & 10 & $33 \%$ \\
\hline & Total & & 30 & $100 \%$ \\
\hline
\end{tabular}

Students' Post-test Result

Table 4.21 The Score of Students' Posttest Result in Control Class

\begin{tabular}{|c|c|c|c|c|}
\hline \multirow{2}{*}{ Respondents } & \multicolumn{3}{|c|}{ The of Aspects Speaking Skills } & \multirow[t]{2}{*}{ Students Score } \\
\hline & exactness & Smoothness & Comprehensibility & \\
\hline R1 & 2 & 3 & 3 & 8 \\
\hline R2 & 3 & 2 & 3 & 8 \\
\hline R3 & 3 & 4 & 3 & 10 \\
\hline $\mathrm{R} 4$ & 3 & 2 & 2 & 7 \\
\hline R5 & 3 & 3 & 2 & 8 \\
\hline R6 & 3 & 2 & 2 & 7 \\
\hline R7 & 3 & 3 & 2 & 8 \\
\hline R8 & 4 & 4 & 2 & 10 \\
\hline R9 & 3 & 4 & 4 & 11 \\
\hline R10 & 4 & 4 & 3 & 11 \\
\hline R11 & 2 & 3 & 2 & 7 \\
\hline R12 & 3 & 3 & 2 & 8 \\
\hline $\mathrm{R} 13$ & 2 & 3 & 3 & 8 \\
\hline R14 & 3 & 2 & 3 & 8 \\
\hline R15 & 3 & 3 & 2 & 8 \\
\hline R16 & 3 & 3 & 3 & 9 \\
\hline R17 & 3 & 2 & 4 & 10 \\
\hline R18 & 3 & 4 & 3 & 8 \\
\hline R19 & 3 & 3 & 4 & 11 \\
\hline R20 & 2 & 4 & 2 & 7 \\
\hline $\mathrm{R} 21$ & 4 & 3 & 3 & 11 \\
\hline $\mathrm{R} 22$ & 3 & 3 & 3 & 9 \\
\hline $\mathrm{R} 23$ & 2 & 4 & 4 & 9 \\
\hline R24 & 3 & 3 & 3 & 10 \\
\hline R25 & 3 & 2 & 2 & 8 \\
\hline R26 & 3 & 3 & 2 & 7 \\
\hline $\mathrm{R} 27$ & 2 & 3 & 2 & 7 \\
\hline R28 & 3 & 3 & 2 & 8 \\
\hline R29 & 2 & 3 & 3 & 8 \\
\hline R30 & 2 & 3 & 2 & 7 \\
\hline
\end{tabular}

Table 4.22 The Rate Percentage Score of Students' Accuracy in Posttest Result in Control Class

\begin{tabular}{cccc}
\hline Classification & Rating & Frequency & Percentage \\
\hline Excellent & 6 & - & $0 \%$ \\
Very good & 5 & - & $0 \%$ \\
Good & 4 & 3 & $10 \%$ \\
Average & 3 & 19 & $63 \%$ \\
Poor & 2 & 8 & $27 \%$ \\
Very poor & 1 & - & $0 \%$ \\
\hline
\end{tabular}


Table 4.23 The Rate Percentage Score of Students' Fluency in Posttest Result in Control Class

\begin{tabular}{|c|c|c|c|}
\hline Classification & Rating & Frequency & Percentage \\
\hline Excellent & 6 & - & $0 \%$ \\
\hline Very good & 5 & - & $0 \%$ \\
\hline Good & 4 & 7 & $23 \%$ \\
\hline Average & 3 & 17 & $57 \%$ \\
\hline Poor & 2 & 6 & $20 \%$ \\
\hline Very poor & 1 & - & $0 \%$ \\
\hline \multicolumn{2}{|c|}{ Total } & 30 & $100 \%$ \\
\hline
\end{tabular}

Table 4.24 The Rate Percentage Score of Students' Comprehensibility in Posttest Result in Control Class

\begin{tabular}{|c|c|c|c|}
\hline Classification & Rating & Frequency & Percentage \\
\hline Excellent & 6 & - & $0 \%$ \\
\hline Very good & 5 & - & $0 \%$ \\
\hline Good & 4 & 4 & $13 \%$ \\
\hline Average & 3 & 12 & $40 \%$ \\
\hline Poor & 2 & 14 & $47 \%$ \\
\hline Very poor & 1 & - & $0 \%$ \\
\hline \multicolumn{2}{|c|}{ Total } & 30 & $100 \%$ \\
\hline
\end{tabular}

\section{Students' Mean Score of pretest and posttest in Class Control}

Table 4.25. Mean score pretest of Students' in Control Class

\begin{tabular}{|c|c|c|c|c|c|c|}
\hline \multicolumn{7}{|c|}{ Statistic Descriptive } \\
\hline & $\mathrm{N}$ & Minimum & Maximum & Sum & Mean & Std. Deviation \\
\hline Pretest cont & 30 & 4 & 9 & 170 & 5.67 & 1.516 \\
\hline Valid N (listwise) & 30 & & & & & \\
\hline
\end{tabular}

Table 4.26 Mean value of posttest Students' in Control Class

Descriptive Statistics

\begin{tabular}{|c|c|c|c|c|c|c|}
\hline & $\mathrm{N}$ & Minimum & Maximum & Sum & Mean & Std. Deviation \\
\hline Posttest cont & 30 & 7 & 11 & 256 & 8.53 & 1.358 \\
\hline Valid N (listwise) & 30 & & & & & \\
\hline
\end{tabular}


Mean value and Standard Deviation of Students' Pretest and Posttest in Experimental Class and Control Class

Table 4.27 Mean Score and Standard Deviation of Students' Pretest and Posttest in Experimental Class

Descriptive Statistics

\begin{tabular}{lcccccc}
\hline & \multirow{2}{*}{ N } & Minimum & Maximum & \multicolumn{2}{c}{ Mean } & Std. Deviation \\
\cline { 2 - 7 } & Statistic & Statistic & Statistic & Statistic & Std. Error & Statistic \\
\hline Pretestexp & 30 & 4 & 12 & 7.57 & .298 & 1.633 \\
Post test exp & 30 & 8 & 15 & 10.53 & .261 & 1.432 \\
Valid N (listwise) & 30 & & & & & \\
\hline
\end{tabular}

The t-test pretest and posttest in Experimental and Control Classes

Table 4.28 Students' Result of t-test from Pre-Test score of Experiment and Control Classes

Group Statistics

\begin{tabular}{lrrrr}
\hline & $\mathrm{N}$ & \multicolumn{1}{c}{ Mean } & \multicolumn{1}{c}{ Std. Deviation } & \multicolumn{2}{c}{ Std. Error Mean } \\
\hline Experiment Class & 30 & 7.57 & 1.633 & .298 \\
Control Class & 30 & 5.67 & 1.516 & .277 \\
\hline
\end{tabular}

Table 4.29 The Probability Score of T-Test of Posttest in Experimental and Control Classes Samples Test

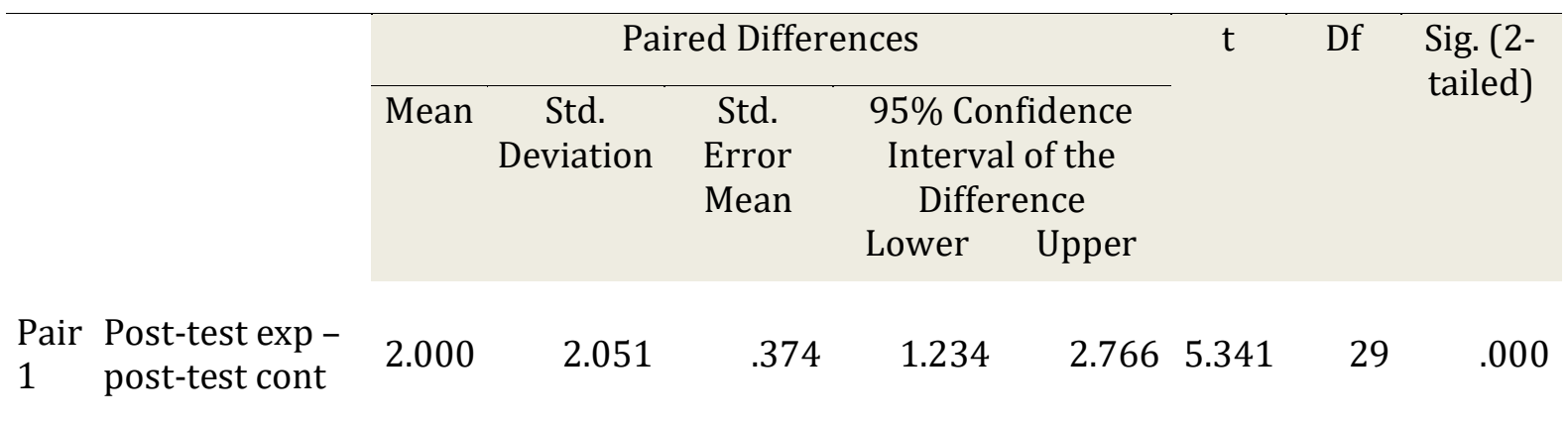

\section{DISCUSSION}

"Based on the research findings, the data analysis above shows that using drama techniques is effective in improving students' speaking skill because of drama teachers and students in doing everything". From shy students to quiet students. When researchers use drama strategy that's where students are excited used three studies, namely Accuracy, Fluency and Comprehensibility. The reason why do the comprehensibility value increase because before students display the drama assigned by students, they are required to understand the drama that they performed. While the value of accuracy and fluency increases because students have trained themselves before 
performing drama. Therefore, they are accustomed to saying the word contained in the dialogue.

In the posttest, it can be seen in the table before after giving continuous treatment using drama techniques. The averages scores of the experimental class of students while the control class of students taught without using drama techniques. Subrabowo said that developing students 'speaking skills through drama parody meant that drama was also effective in improving students' speaking skill.

In this section, researchers take 3 students as representations that have different abilities, namely students R1, R2, and R10. From these three students, there are differences in the comparison of speaking skills in drama techniques, namely high, medium and low in the experimental class.

The first student is the student (R1), the study found that students could explain the topic in the pretest because he is fluent and comprehensive in explaining the topic. In addition, after researchers provide treatment about drama techniques, students are increasingly eager to put out the words spoken. Before the researcher gave treatment, he got a score of 12 in the pretest and after giving treatment, students got 15 scores in the posttest.

The second student is a student (R2) students have a moderate ability to describe a topic. After research provides treatment about drama, these students have the motivation to learn to speak, especially in terms of confidence to appear in public. After that, before the researcher gave treatment, he got a score 11 of pretest and after giving treatment the student got 12 scores on the posttest.

The third student is a student (R10). This student has a different comparison between the two students above because he has a very low level of student A and student B. After the researcher gives treatment about drama students are lazy to put out words and are ashamed to appear in front. Before the researcher gave treatment, he got 9 scores on the pretest and after giving the treatment, students got 10 scores on the posttest. In the control class, researchers found differences from the experimental class. The controlled class has low talk. Besides that, after the researcher teaches speaking without drama, students cannot explain the topic well.

\section{CONCLUSION}

"Based on the research findings it can be concluded that the use of Drama techniques is effective to improve students' speaking abilities at SMPN 9 Palopo". In other words, it can be proven that there are significant differences in the learning outcomes of students who learn to speak through Drama techniques with students who take learning without Drama techniques. "Based on data analysis in the experimental class, the post-test average score is higher than the pre-test average score $(10,5300>7.5700) "$. "While in the control class, the posttest average score was also higher than the pretest average score $(8.5300>5.6700) "$. "Based on the analysis of the data it can be concluded that the teaching skills of speaking using effective drama techniques at SMPN 9 Palopo". It can be proven 
that the scores of students in the experimental class are higher than students in the control class.

\section{REFERENCES}

Aini, Kuratul.2014 "Improving speaking ability of the third yeard students at third yeard students at MTSn model Makassar through education Drama". 2014: Makassar.

Afizaldeni, Improving Student' Speaking through Communicative Language Teaching Methode at MtsJa-alhaq, Sentot Ali Basa Boarding School of Bengkulu, Indonesia, (State Institute of Islamic Studies (IAIN) Bengkulu, Indonesia 2012), p. 127

Brown, 2001. Teaching by principles: An Interactive Approach to Language Pedagogy. New York: Pearson Education.

Brown, Doglas H. (2004). Language Assessment: Principle and Classroom Practices. United State of America: Pearson Education, Inc.

David, Nunan. 2003. Interaction speech is more fluid and unpredictable that transactional speech.

Djumingngin, In Rahmanto. 2004: 42. Teaching of strategy Drama

Helen, Nicholes. 2000. Teaching Drama 11-18ed. London: Continuum.

H, M Abram. 1971. A Glossary of Literary Terms (3 ${ }^{\text {rd }}$ ed.). New York: Holt, Rinehart and Winstom, Inc.

Heaton, B. J. "Longman Handbooks for Language Teachers". (London and New York, 1990)

Iksan, M., \& Palangngan, S. T. (2018). PEMBERDAYAAN REMAJA MASJID SEBAGAI FASILITATOR PEMBELAJARAN BAHASA INGGRIS DI DESA LESTARI KECAMATAN TOMONI KABUPATEN LUWU TIMUR. Prosiding, 3(1).

Inayah, Ratih Inayah. Improving Students' Speaking Skill Through Story Telling Technique, (STKIP SiliwangiBandung, ELTINJurnal, Vol 3/1, April 2015), p. 27-28

Jacobs, Ary. Donald.LC, and Razavieh, An Introduction to Research in Education: Third Edition (New York: CBS College Publishing, 1985) 302.

J, Harmer. 2001. The practise of English language teaching. London: Pearson Education Limited.

Kayi, 2016. Teaching Speaking: Activities to promote speaking in the second language. http://iteslj.org/Articles/kayi-TeachingSpeaking.html. retrieved on Dec $10^{\text {th }}$, 2009 at $1.22 \mathrm{am}$ 
Lestari, Suci. 2018 "Developing students speaking through Drama performance of SMK Negeri 1 metro". Lampung: education faculty Lampung University

Latief, Adnan M. Tanya Jawab Metode Penelitian Pembelajaran Bahasa (Malang: UNM Press, 2010) 120.

Martin, Bygate. 2000. Teaching and Researching Speaking. London: Longman.

Richard, 2002. Approachers and Methods in Language Teaching (2 ${ }^{\text {nd }}$ Ed.). Cambridge: University Press

Richard,1990: 233. Says that there are many reasons causing English learner poor in speaking skill.

Susilawati, Ery Rr. "Improving students' speaking skill using Drama at the eleventh-grade students of language class of MAN YOGYAKARTA II in the academic year of. 20122013. Yogyakarta

S, Thornbury.2005. How to teach Speaking. Harlow: Pearson Education Ltd.

Procharza, Anton. 2006. Drama in Modern Language TeachingPart 2. Frankfurt: Wien. 